\title{
Community Nurses' Knowledge, Attitude, and Practice Towards Child's Growth and Development Promotion Program in the Community Health Care Center
}

\author{
Ferika Indarwati ${ }^{1,{ }^{*}}$ Khoirunnisa Miyono1, Andri Putriasi $^{1}$, Siska Manunggar ${ }^{1}$, Nisa \\ Hasanah $^{1}$

\begin{abstract}
${ }^{1}$ School of Nursing, Faculty of Medicine and Health Science, Universitas Muhammadiyah Yogyakarta, Indonesia *Corresponding author. Email:ferika.indarwati@umy.ac.id
\end{abstract}

\begin{abstract}
Promoting child growth and development is one of the Indonesian community health center's priority programs. Children's growth and development at early ages play a crucial role in defining children's future health trajectories. This study aims to describe community nurses' knowledge, attitude, and practice towards child growth and development promotion programs in the community health center. A cross-sectional survey was conducted in the Bantul district, Indonesia, involving 73 community health nurses working in the community health center. The sample was recruited using multistage random sampling from 27 community health centers in the Bantul district. Three valid and reliable questionnaires were used to measure nurse's knowledge, attitude, and practice. The Guttman scale knowledge questionnaire consisted of 22 questions. The nurses' attitude and practice questionnaires used a four-point Likert scale and consisted of 23 and 21 questions, respectively. The assessment results were categorised into excellent (scored 75$100 \%$ ), moderate (scored 56-74\%) and poor (scored $<56 \%)$. The results showed that $71(97.3 \%)$ and $72(98 \%)$ nurses had adequate knowledge and attitude towards child' growth and development promotion programs in public health centers, respectively. Nevertheless, only $45(62 \%)$ of nurses indicated excellent practice towards the implementation of the growth and development promotion program. Among demographic variables measured, only education was associated with nurses' practice $(p<0.001)$. Data from this study indicated that the community nurses might require more training related to the implementation of the health promotion program for children in the community health center to increase their practice and service to promote children's growth and development in the community health center.
\end{abstract}

Keywords: Children, growth and development, health promotion, nursing

\section{INTRODUCTION}

Child growth and development consist of several stages, including infants (0-1 years), toddlers (1-2.5 years), pre-school (2.5-5 years), school ages (5-11 years), to adolescents (11-18 years). In each of these stages, children have particular and significant physical, cognitive, self-concept, coping patterns, and social, behavioral changes [1]. Child growth and development are influenced by the frequency and intensity of children's interactions with their environment. Quality and effective interactions will have a good impact on children. The closest and essential environment for children is their family, as the parents' attitude determines the child's development. Parents who are willing to accept the child's condition, provide support, and create an environment conducive to growth and development will optimize their child's growth and development. On the other hand, frustrated parents would instead feel guilty or reject their child, which can hinder their growth and development [2].

Developmental disorders can cause external and internal growth disorders in the human body, ranging from simple to complex. Extrinsic factors can influence this pathological state, for example, environment and intrinsic factors, called genes. Congenital disabilities can come from changes in the environment during the pregnancy, such as toxic conditions, hypoxia that causes cerebral palsy, and mental disabilities [3]. 
The best approach to prevent a child's growth and developmental delays is through health promotion and education [4]. These promotion and education programs should comprise all aspects of a child's growth and development, including anticipatory guidance for parents or caregivers. The identification of danger or conflict in each developmental phase allows parents to identify and prevent potential problems [5]. Nevertheless, some studies have reported that parents or caregivers have low knowledge on preventing and monitoring child growth and development. In this situation, healthcare workers in primary community settings have crucial roles in facilitating these families to understand the potential risks that may affect their children's healthy growth and development. Community health care workers are also mandated to ensure that children in their service area should achieve their growth and development potentials [6]. Community health workers have become progressively recognized and acknowledged as an effective and efficient intervention central to increasing community-based health services, particularly in low and middle-income countries such as Indonesia [7].

Community/public health center in Indonesia is an executive unit located under a municipal health office. These health services provide curative, disease management, and rehabilitative services, focusing on promotive and preventive services [8]. The public health centers also have several programs to improve maternal and child health care in the community. The community health service in Bantul regency has several programs to improve children's growth and development. Several programs that have been carried out routinely in the center include the detection of child growth and development (DTKB) program [9]. Although the program has been carried out to identify and detect the pediatric population's growth and developmental delay, many children in Bantul Regency experience growth and development disorders. There have been 17,233 children that had been screened by the community health center, $1.9 \%$. According to data from the National Health Survey conducted by the Indonesian Ministry of Health 2018, 22.86\% of children in Bantul Yogyakarta had growth and developmental problems [10 - 12]. As part of the frontline's healthcare staff in the primary public health care settings, community health workers have a crucial role in reducing the proportion of children experiencing growth and developmental delays. Therefore, this study aims to investigate the knowledge, attitudes, and practice of the community health workers on promoting the growth and development of children in community health care centers in Bantul, Yogyakarta, Indonesia.

\section{METHODS}

A cross-sectional study was conducted in 27 community health care centers in Bantul Yogyakarta, Indonesia. The number of populations in this study was 255 nurses. The multistage random sampling technique was used to determine the number of samples in this study. The first stage was random cluster sampling. This technique was used to select 17 out of 27 community health centers in the Bantul region to represent 17 districts in Bantul. The second stage was simple random sampling.
It was conducted to obtain the individual sample of each cluster/community health care center selected from the first stage. This study's final sample was 73 nurses from 17 primary health care centers in the Bantul district.

Valid and reliable questionnaires were used to measure nurse knowledge, attitude, and practice. The Gutmann scale knowledge questionnaire consisted of 22 questions. The nurses' attitude and practice questionnaires used a four-point Likert scale and consisted of 23 and 21 questions, respectively. All of the questionnaires consisted of components measured every four constructs of the child's growth and development program in the community health center, namely the concept of the health promotion program, program targets (primary, secondary and tertiary), child's growth and development promotion strategies, and the important steps of the child growth and development promotion program. The assessment results were categorised into excellent (scored 75-100\%), moderate (scored $56-74 \%$ ) and poor (scored $<56 \%$ ). Ethical clearance for this study was obtained from the Institutional review board with reference number: 187/EP-FKIK UMY/IV/2015).

Data analysis was conducted using SPSS ${ }^{\mathrm{TM}}$; univariate analysis was used to analyze the descriptive estimates of the knowledge, attitudes, and practices of health workers about the promotion of child development. Chi-square or Fisher's exact test was used to investigate the relationship between demographic data and the nurse's practice toward the health promotion program.

\section{RESULTS}

The survey obtained data from 73 healthcare staff from 17 community health centers located in Bantul, Yogyakarta, Indonesia. The demographic characteristics of the respondents are summarized in table 1.

Table 1 Characteristics of Respondents (N:73)

\begin{tabular}{lcc}
\hline \multicolumn{1}{c}{ Variable } & Frequency & Percentage \\
\hline Age & & \\
- 20-40 years old & 41 & $56.2 \%$ \\
- 41-60 years old & 32 & $43.8 \%$ \\
Education & & \\
- Diploma 3/lower & 59 & $80.8 \%$ \\
- Diploma 4/higher & 14 & $19.2 \%$ \\
Working Experience & & \\
- 2-12 years & 29 & $39.7 \%$ \\
- 13-23 years & 20 & $27.4 \%$ \\
- 24-34 years & 24 & $32.9 \%$ \\
\hline
\end{tabular}

Table 1 shows that most of the respondents $(41,56.2 \%)$ were $20-40$ years old, had a Diploma of 3 education level $(59,80.8 \%)$, and had $2-12$ years of working experience in community health care settings. 
Table 2. Nurses' knowledge of the child's growth and development promotion program (N:73)

\begin{tabular}{lcc}
\hline \multicolumn{1}{c}{ Variable } & Frequency & Percentage \\
\hline \multicolumn{2}{l}{ Nurse's Knowledge of the child health promotion program } \\
- Concept of the health promotion program \\
Excellent & 63 & \\
Moderate & 10 & $86.3 \%$ \\
- The target of the health promotion program & $13.7 \%$ \\
Excellent & 63 & \\
Moderate & 10 & $86.3 \%$ \\
- Strategies of the health promotion program & $13.7 \%$ \\
Excellent & 59 & $80.8 \%$ \\
Moderate & 14 & $19.2 \%$ \\
- Steps to implement the health promotion program \\
Excellent & 64 & $87.7 \%$ \\
Moderate & 9 & $12.3 \%$ \\
- Overall knowledge & \multicolumn{2}{|c}{} \\
Excellent & 71 & $97.3 \%$ \\
Moderate & 2 & $2.7 \%$ \\
\hline
\end{tabular}

Table 2 indicates that most community nurses have sufficient knowledge across the components of a child's growth and development promotion program in the community health center. The lowest score was in the knowledge of the growth and development promotion strategies, with only $50(80.8 \%)$ nurses having good knowledge on this concept.

As per table 3, the majority of nurses $(72,98.6 \%)$ had an excellent attitude towards the child growth and development program. The number of nurses in the excellent attitude category was also relatively similar across this study's four dimensions.

Table 3. Nurse's attitude towards the child's growth and development promotion program (N:73)

\begin{tabular}{lcc}
\hline \multicolumn{1}{c}{ Variable } & Percentage \\
\hline Nurse's Attitude of the child health promotion program \\
- Concept of the health promotion program \\
Excellent & 72 & \\
Moderate & 1 & $98.6 \%$ \\
- The target of the health promotion program & $1.4 \%$ \\
Excellent & 71 & $97.3 \%$ \\
Moderate & 2 & $2.7 \%$ \\
- Strategies of the health promotion program & \\
Excellent & 72 & $98.6 \%$ \\
Moderate & 1 & $1.4 \%$ \\
- Steps to implement the health promotion program \\
Excellent & 71 & $91.8 \%$ \\
Moderate & 2 & $8.2 \%$ \\
- Overall attitude & \\
Excellent & 72 & $98.6 \%$ \\
Moderate & 1 & $1.4 \%$ \\
\hline
\end{tabular}

Based on table 4, the nurse practice related to child growth and development promotion in the community health center was relatively low, with only $45(61.6 \%)$ nurses reported adequate practice in the promotion program. The lowest percentage was found in the implementation of the steps mandated in undertaking the growth and development promotion program. Only 38
$(52 \%)$ nurses reported good practice in conducting and following steps in the promotion program.

Table 4. Nurse's practices of the child's growth and development promotion program (N:73)

\begin{tabular}{lcc}
\hline \multicolumn{1}{c}{ Variable } & Frequency & Percentage \\
\hline \multicolumn{2}{c}{ Nurse's practice on child health promotion program } \\
- Promoting child growth and development \\
Excellent & 53 & \\
Moderate & 20 & $72.6 \%$ \\
- Achieving the health promotion program targets & $27.4 \%$ \\
Excellent & 47 & $64.4 \%$ \\
Moderate & 26 & $35.6 \%$ \\
- Implementing the health promotion program strategies \\
Excellent & 42 & $57.5 \%$ \\
Moderate & 31 & $43.5 \%$ \\
- Implementing the steps of the health promotion program \\
Excellent & 38 & $52 \%$ \\
Moderate & 35 & $48 \%$ \\
- Overall practice & & \\
Excellent & 45 & $61.6 \%$ \\
Moderate & 28 & $38.4 \%$ \\
\hline
\end{tabular}

Fisher's exact test between age and nurse's practice showed that there was no significant association between these two variables $\left(\chi^{2}: 3.86, \mathrm{p}: 0.273\right)$. Similarly, the association between working experience and a nurse's practice was also insignificant $\left(\chi^{2}: 5.90, \mathrm{p}: 0.052\right)$. Only education was significantly associated with the nurse's practice towards a child's growth and development promotion programs in the community health center $\left(\left(\chi^{2}\right.\right.$ : $26.9, \mathrm{p}<0.001)$

\section{DISCUSSION}

Community health workers are providers of outreach, education, and enrollment in primary care [13]. As liaisons between health systems and communities, they facilitate access and improve medical care quality and cultural competence, emphasizing preventive and primary care $[14-15]$. Based on the research results, most community health care workers participating in this study were 20-40 years old. Similar findings were reported by Baharutan (2015), that the age group of the community health care workers in the Manado community health center, Indonesia, was 26-35 years old [16]. Data from the national health survey also showed that the age group of 26-35 years was the largest labor force group in Indonesia compared to other age groups. This age group was also called the productive period, where a person had high energy, creativity, and productivity [17].

In this study, most of the respondents had a nursing diploma; only a small percentage had an education level higher than diploma 3 . This result was similar to findings reported by Nadya et al. (2016) in their study of health promotion activities in Bandung city Indonesia that 17 out of 25 of the health care workers were found to hold diploma degree. Most nurses participating in this study had 2 to 12 years of working experience in the 
community health center [18]. Working experience is considered as one of the determinants of nurse competence. The differences in experience will lead to different abilities in the performance of services provided to patients [19]. The experience becomes a factor in shaping a person's attitudes, as it will be the basis of forming a good attitude [19]

The number of community nurses who had excellent knowledge and attitude towards a child's growth and development promotion program was relatively high. Different factors, such as education, training, information, and experience, are reported to influence nurses' knowledge and attitude [20]. The results of research conducted by Hong \& Lee (2014) showed that there were several factors affecting the knowledge of health workers such as level of education, number of training, working experience, and position at work. This research explained that the higher the health workers' education level is, the stronger the knowledge and desire to share the knowledge will be [21-22]. The level of knowledge of particular subjects was also reported to influence someone's attitude and practice in those areas. In this study, it was observed that the community health workers in Bantul also had a good attitude towards the growth and development promotion program held in the community health center.

The attitudes of the community health workers in this study in providing health promotion were mostly excellent. This finding is similar to a study conducted by Debuo et al. (2017) that more than $75 \%$ of public health nurses positively promoted child growth and development in the community health care center. A good attitude influences the practice or implementation of the health promotion programs in the public health center. It is also predicted that good knowledge and attitude results in good practice. However, in this study, even though the community health nurses had good knowledge and attitude towards the promotion program, the level of practice did not assimilate with the level of knowledge and attitude. Nevertheless, the nurse implementation/practice towards the promotion programs was relatively low [20].

In this study, education was significantly associated with the community nurse's practice in the health promotion program. Research conducted by Yuniarti et al. (2012) revealed that education was significantly associated with care practice/performance, indicating a relationship between education and health promotion officers' performance at the Pati District Office [22]. According to Debuo et al., (2017), the longer the work experience was, the better the employee's work experience and performance would be [24]. This research is in line with the research of Simamora (2010), which stated that nurses who had worked for more than two years had good behavior compared to nurses whose length of work was less than two years [20].

\section{CONCLUSION}

Nurses' knowledge and attitude towards growth and promotion programs for children in the primary health care centres were considerably high, indicating that nurses had established sufficient information and a positive perspective on the promotion program. Nevertheless, nurses' practice related to the implementation of the program was still relatively low. These findings suggested that future research is needed to investigate barriers for nurses to implement the child's growth and promotion program and formal training and supervision to support nurses in implementing all of the programs at the primary health care centers.

\section{AUTHORS' CONTRIBUTIONS}

Ferika Indarwati: Conceptualization, Methodology, Investigation, Validation, Formal analysis, Writing Original Draft, Writing - Review and Editing. Khoirunnisa Miyono, Andri Putriasi, Siska Manunggar, Nisa Hasanah: Investigation, Analysis, Writing - Review and Editing.

\section{ACKNOWLEDGMENTS}

The researcher acknowledges Universitas Muhammadiyah Yogyakarta for providing funding for this study.

\section{REFERENCES}

[1] Adriana, Dian. 2011. Tumbuh Kembang dan Terapi Bermain pada Anak. Jakarta. Salemba Medika.

[2] Soetjiningsih. 2012. Tumbuh Kembang Anak. Jakarta. EGC

[3] Britto, P. R., Lye, S. J., Proulx, K., Yousafzai, A. K., Matthews, S. G., Vaivada, T., Perez-Escamilla, R., Rao, N., Ip, P., \& Fernald, L. C. (2017). Nurturing care: promoting early childhood development. The Lancet, 389(10064), 91-102.

[4] Freeman, P. A., Schleiff, M., Sacks, E., Rassekh, B. M., Gupta, S., \& Perry, H. B. (2017). Comprehensive review of the evidence regarding the effectiveness of community-based primary health care in improving maternal, neonatal and child health: 4 . child health findings. Journal of global health, 7(1).

[5] Hammarberg, K., \& Taylor, L. (2019). Survey of Maternal, Child and Family Health Nurses' attitudes and practice relating to preconception health promotion. Australian Journal of Primary Health, 25(1), 43-48.

[6] Hady, M. Hamzah, A. \& Nurhayani. 2015. Gambaran Kinerja Tenaga Kesehatan Ibu dan Anak (KIA) di Puskesmas Se-Kabupaten Sidenreng 
Rappang. Makasar. Diakses 30 Oktober 2014, dari http://repository.unhas.ac.id.

[7] Hartono, B. 2010. Promosi Kesehatan di Puskesmas dan Rumah Sakit. Jakarta. Rineka Cipta.

[8] Richter, L. M., Daelmans, B., Lombardi, J., Heymann, J., Boo, F. L., Behrman, J. R., Lu, C., Lucas, J. E., Perez-Escamilla, R., \& Dua, T. (2017). Investing in the foundation of sustainable development: pathways to scale up for early childhood development. The Lancet, 389(10064), 103-118.

[9] Hockenberry, M. J., \& Wilson, D. (2018). Wong's nursing care of infants and children-E-book. Elsevier Health Sciences.

[10] Departemen Kesehatan Republik Indonesia. 2014. Profil Kesehatan Indonesia Tahun 2013. Jakarta.

[11] Departemen Kesehatan Republik Indonesia. 2011. Promosi Kesehatan di Daerah Bermasalah Kesehatan: Panduan bagi Petugas Kesehatan di Puskesmas. Jakarta.

[12] Departemen Kesehatan Republik Indonesia. 2018. Profil Kesehatan Indonesia Tahun 2018. Jakarta.

[13] Black, M. M., Walker, S. P., Fernald, L. C., Andersen, C. T., DiGirolamo, A. M., Lu, C., McCoy, D. C., Fink, G., Shawar, Y. R., \& Shiffman, J. (2017). Early childhood development coming of age: science through the life course. The Lancet, 389(10064), 77-90.

[14] Perry, H. B., Rassekh, B. M., Gupta, S., Wilhelm, J., \& Freeman, P. A. (2017). Comprehensive review of the evidence regarding the effectiveness of community-based primary health care in improving maternal, neonatal and child health: 1. rationale, methods and database description. Journal of global health, 7(1).

[15] Richter, L. M., Daelmans, B., Lombardi, J., Heymann, J., Boo, F. L., Behrman, J. R., Lu, C., Lucas, J. E., Perez-Escamilla, R., \& Dua, T. (2017). Investing in the foundation of sustainable development: pathways to scale up for early childhood development. The Lancet, 389(10064), 103-118.

[16] Sewa, R., Tumurang, M., \& Boky, H. (2019). Pengaruh Promosi Kesehatan Terhadap Pengetahuan dan Sikap dengan Tindakan Pencegahan Stunting oleh Kader Posyandu di Wilayah Kerja Puskesmas Bailang Kota Manado. KESMAS, 8(4).

[17] Susanto, T., Yunanto, R. A., Rasny, H., Susumaningrum, L. A., \& Nur, K. R. M. (2019).
Promoting Children Growth and Development: A community - based cluster randomized controlled trial in rural areas of Indonesia. Public Health Nursing, 36(4), 514-524.

[18] Mahardika, D. 2013. Pengaruh Pendidikan Kesehatan Terhadap Peningkatan Pengetahuan Ibu tentang Deteksi Dini Gangguan Tumbuh Kembang Anak Usia 1-5 Tahun di Posyandu Kasihan 1 dan 2 Bantul Yogyakarta. Karya Tulis Ilmiah Strata Satu. Universitas Muhammadiyah Yogyakarta. Yogyakarta.

[19] Peacock-Chambers, E., Ivy, K., \& Bair-Merritt, M. (2017). Primary care interventions for early childhood development: a systematic review. Pediatrics, 140(6)

[20] Simamora, A. 2010. Pengaruh Pengetahuan Petugas Kesehatan terhadap Pelaksanaan Program Promosi Kesehatan di Puskesmas di Kabupaten Humbang Hasundutan. Karya Tulis Ilmiah Strata Dua. Universitas Sumatera Utara. Medan.

[21] Maulana, H \& Yudha, E. (Eds). 2009. Promosi Kesehatan. Jakarta. EGC.

[22] Yuniarti. Shaluhiyah, Z \& Widjanarko, B. 2012. Kinerja petugas Penyuluh Kesehatan dalam Praktek Promosi Kesehatan di Dinas Kesehatan Kabupaten Pati. Jurnal Promosi Kesehatan Indonesia. Vol. $7 /$ No. 2 / Agustus 2012

[23] Sari, N. 2010. Hubungan Kegiatan Bina Keluarga Balita (BKB) dan Tumbuh Kembang Balita di Kelurahan Simpang Tetap Darul Ichsan Kecamatan Dumai Barat Kota Dumai. Karya Tulis Ilmiah Strata Satu. Universitas Sumatera Utara. Medan.

[24] Debuo, T., Appiah, P. K., Kweku, M., Asalu, G. A., Ahiabor, S. Y., Takramah, W. K., \& Duut, A. B. (2017). Caregivers knowledge, attitude and practices on child growth monitoring and promotion activities in Lawra District, Upper West Region of Ghana. Science Journal of Public Health, 5(1), 20 30 . 